\title{
Corporate communications are worth a million
}

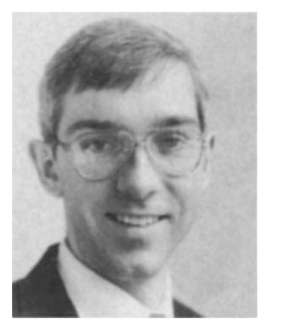

David Stone is managing

director at Cowen \& Co. (Boston,

$M A)$.
Chiron (Emeryville, CA) and Berlex Laboratories (Wayne, NJ) are currently gearing up for the launch of Betaseron, a breakthrough treatment for multiple sclerosis(MS) that should become the biotechnology industry's latest major success story. Betaseron's blockbuster potential is underscored by its ability to reduce the frequency and severity of the debilitating symptoms of relapsing-remitting MS. Analysts have pegged the market potential of Betaseron at $\$ 500$ million to $\$ 1$ billion, or even more.

Set against this enormous potential, the success of Betaseron on Wall Street may seem assured. However, this is not the case. For when measured by Chiron's stock performance, the market's judgment of success or failure will rest upon the company's ability to set and manage investor expectations. Fortunately, for Chiron and for the industry, this job is in the capable hands of Larry Kurtz, the firm's vice president of corporate communications, a consummate professional at managing the analysts' unruly ranks.

Unfortunately, most biotechnology companies do not employ a Larry Kurtz, or anyone close, to handle the communications function. If they did, perhaps the group's characteristic volatility would be somewhat lessened. Moreover, we might all have an easier time raising the needed capital to keep biotech's prolific research-and-development engines turning. Remember that emerging companies travelling the long road to products and profits have nothing to sell but words. Their stock is their only merchandise, and yet they rarely hire a manager devoted solely to this critical task.

Indeed, a capable communications director is the million-dollar manager no firm should be without. Perhaps this assertion sounds hyperbolic. Then consider the all-to-frequent experience of investors in biotechnology companies. The stock is down, maybe on news, rumors. or nothing at all. You have to decide whether to bail out, sit tight, or buy more shares. You call the company, but no one is available to speak with you. And no one calls back, some- times for days.

So how much does this negligence cost the company? In the words of a portfolio manager we know, "If I have to be anxious about my position for a couple of hours, instead of a couple of days, maybe I won't sell the stock. And that could be worth a dollar or two per share the next time the company raises money." Since a typical development-stage company might sell 2 million to 3 million shares every couple of years, that "dollar or two" could mean an extra $\$ 4$ million to $\$ 6$ million on every $\mathrm{fi}$ nancing. Thus our phrase "the million-dollar manager no firm should be without." And such managers cost a lot less than that.

In the face of this simple logic, where do firms go wrong? Many mistakenly believe that calls from Wall Street should only be taken by senior managers, such as the chief executive officer or chief financial officer. But these individuals generally fail to meet the first and most important qualification as investor contacts, and that is prompt access. This requirement makes investor relations a full-time job, even for a small and newly public company. Yet many firms who appreciate this point make the second common mistake of hiring only a full-time message taker. To do the job well, a communications director must have sufficient knowledge of the firm's technology, programs, and strategy to be able to answer investor's questions directly or obtain answers quickly from other departments. Finally, a company can maximize shareholder value only when the person in charge of the communications function is made an integral part of the management team. In this way, the communications director can provide a vital twoway link with the investment community, not only communicating the company's message, but also contributing a view of the financial and competitive environment that can improve management's decision making.

Having hired a capable communications manager, a company can set about improving the investor- relations process. This can begin with a simple understanding that the stock is a product, investors are customers, and good customer service boosts sales. When companies want to improve their stock price-and what company doesn't-they should think in terms of building more and better relationships with current and potential investors. This is accomplished primarily by personal salesmanship, through direct contact with institutional investors and with research analysts in the brokerage community. Building these customer relationships requires time, repetitive effort, and a developed understanding of how investors and analysts do their jobs. Long-term investors are the shareholders every company wants most, but few seem to appreciate the work required. These are not the folks who can buy a stock on one piece of news or simply because the shares are moving up. These investors must get to know the company before they buy the stock, sometimes over many months of study and one or more personal visits. Once they've taken a position, they will need to stay informed through frequent contact. High maintenance though they are, these are also the investors who can step into the breach when a stock is down or when the company needs to raise money in a tepid market.

Investor relations is a service business, and like other such businesses, the simple parts are often what break down. For example, some biotechnology companies invest tremendous resources to attract attention-printing flashy annual reports, issuing frequent press releases, and hiring public-relations firms-only to treat the resulting investor inquiries with scorn or neglect. All too often, we hear complaints from institutions that they are having great difficulty getting calls returned or setting up on-site visits. Potentially important institutional investors end up getting turned off, or turned away, simply because the person taking calls at the company doesn't know who they are. In the long run, this can be an expensive mistake. /// 